\title{
PENGARUH LINGKUNGAN KERJA DAN DISIPLIN KERJA TERHADAP KEPUASAN KERJA KARYAWAN PADA KANTOR SAMSAT PAINAN
}

\author{
Ifriana, Febsri Susanti \\ Sekolah Tinggi Ilmu Ekonomi KBP \\ ifriana12@gmail.com \\ febsrisusanti@akbpstie.ac.id
}

\begin{abstract}
Good quality products in the eyes of consumers will encourage consumers to make purchasing decisions against these products. The purpose of this study is to determine the effect of product quality on consumer decisions in buying lubricants meditran SC on CV. Dul Service Padang. This type of research is quantitative. The population of this study were consumers who bought Pertamina lubricant brand Meditran SC on CV. Dul Service Padang consisting of 53 people is taken by simple random sampling. Data were processed by using simple linear regression using questionnaire. The results showed that there is influence of product quality to consumer decision in buying lubricant Meditran SC at CV. Dul Service Padang $(p=0,000)$ with adjusted value of Rsquare 0.150 means as much as $15 \%$ variable of product quality influence buying decision and the rest $85 \%$ influenced by other variable outside research variable.
\end{abstract}

Keywords: Product Quality, Purchase Decision

\section{PENDAHULUAN}

Keberhasilan organisasi dalam mencapai tujuan selalu berperan besar didalamnya tenaga kerja yang berkontribusi di dalamnya dan seluruh sumber daya manusia yang ada. Maka dari itu perlunya di adakan pengembangan sumber daya manusia guna memperoleh sumber manusia yang berkualitas untuk mencapai tujuan organisasi atau perusahaan dengan optimal dan mendorong visi dan misi suatu organisasi (Dessler, 2011) menyatakan bahwa di dalam perusahaan manajemen yang mengurus sumber daya manusia berkontribusi dalam mengelola unsur sumber manusia dan memunculkan potensi yang ada secara efektif untuk tercapainya tujuan dan memuaskan untuk organisasi atau perusahaan.

Menurut (Vera, Simbolon, Seno Andri, \& Si, 2016) defenisi kepuasan dalam bekerja yakni di saat emosional pegawai maupun karyawan yang terjadi maupun tidak terjadi, di saat ada nilai titik temu antara balas jasa yang memang diinginkan seseorang. Kepuasan kerja merupakan perasaan gembira atau positif yang dimiliki oleh pegawai terhadap pekerjaan itu sendiri, ganjaran yang diterima ataupun perasaan yang berhubungan dengan dirinya. Maka kepuasan menyangkut sifat dan perasaan yang akan nantinya berdampak pada kinerja karyawan. Oleh karena itu pimpinan dituntut lebih profesional agar mampu menimbulkan kepuasan kerja pada bawahannya. 
Kejadian yang terjadi saat ini adalah masalah perpindahan pegawai dari suatu tempat ke daerah lain atu perusahaan lain., yang nantinya akan menimbulkan masalah yakni masalah kepuasan kerja karyawan.masalah itu timbul kdikarenakan karyawan yang sudah bekerja dalam perusahaan yang sebelumnya sudah mendapatkan kenyaman bahkan motivasi kerja dalam bagan perusahaan tersebut, jika terjadi perpindahan tempat mereka bekerja belum tentu sama yang dirasakan pada perusahaansebelumnya.

SAMSAT dapat diibaratkan bagi suatu cabang birokrasi yang berada di tengah-tengah birokrasi dan masyarakat. Pada posisinya dimasyarakat cabang SAMSAT agar menyalurkan pelayanan yang memuaskan kepada masyarakat untuk pengguna layanan baik pelayanan barang maupun pelayanan jasa. Cakupan dengan pemungutan pajak kendaraan bermotor maka SAMSAT berkewajiban bagi memberikan pelayanan yang optimal.

Hal yang bnerhubungan dengan masalah diatas, suatu instansi sqwasta ataupun negri. Keterlibatan karyawan didalamnya sebagai sumber manusia dlam instansi tersebut akan membantu menggapai suatu tujuan sesuai misi dan visi. tetapi dari hasil observasi awal yang telah peneliti lakukan yang terjadi di Kantor Samsat Painan tingkat kepuasan kerja karyawan masih rendah, dapat dilihat dari karyawan tidak bersemangat dalam melakukan pekerjaannya, kelengkapan sarana kerja, serta kehangatan hubungan kerja dengan atasan ataaupun sesama kerja. Kebutuhan tersebut yaitu sumber-sumber kepuasan kerja yang perlu mendapat pemenuhan yang semakin baik Hal ini tentu akan berakibat pada penurunan kepuasan kerja pada karyawan kantor Samsat Painan dan tidak tercapainya target yang telah ditentukan oleh instansi.

Hal ini berarti indikasi bahwa kepuasan kerja karyawan kantor Samsat Painan menjadi hal yang menarik untuk diteliti. (Kreitner \& Kinicki, 2014) secara spesifik mendeskripsikan kepuasan kerja sebagai perasaan positif seseorang atas pekerjaannya yang diberi dari suatu evaluasi terhadap karakteriskik kepuasan itu sendiri. Perasaan positif ini umumnya identik dengan rasa bahagia dan nyaman karena harapan seseorang dari pekerjaannya telah banyak terpenuhi.

Menurut (Hariani, Isyandi, \& Machasin, 2015) yang menjadi faktor dalam kepuasan kerja yakni faktor lingkungan kerja, yaitu teman sejawat, kompensasi atau imbalan dan keadaan fisik ruangan. Lebih lanjut (Sutrisno, 2013) mengemukakan bahwa lingkungan kerja juga dapat diartikan keseluruhan sarana dan prasarana kerja yang ada di sekitar karyawan yang sedang melakukan pekerjaan yang dapat mempengaruhi pelaksanaan pekerjaan, lingkungan kerja ini meliputi tempat bekerja, fasilitas, dan alat bantu pekerjaan, kebersihan, pencahayaan, ketenangan, termasuk juga hubungan kerja antara orang-orang yang ada di tempat tersebut.

Lingkungan kerja yakni bagian yang penting dalam perusahaan. Meskipun lingkungan kerja tidak melaksanakan proses produksi dalam suatu perusahaan, namun lingkungan kerja mempunyai pengaruh langsung terhadap para karyawan yang melaksanakan proses produksi tersebut. Masalah mengenai kondisi lingkungan kerja mungkin terlihat sepele namun dampak yang ditimbulkan sangat besar serta menyangkut masalah keuntungan dan kerugian perusahaan dan sampai saat ini masih banyak ditemukan instansi yang kurang memperhatikan hal tersebut. 
Berdasarkan wawancara awal dengan seorang karyawan yang bekerja di kantor Samsat Painan menjelaskan bahwa kondisi ruang kerja sekarang kurang nyaman sehingga dibutuhkan perubahan salah satunya adalah dengan mengubah warna ruang kerja. Keadaan ruangan kerja di salah satu bidang memang kurang ideal hal ini tergambar dengan masih menyatunya ruangan kepala sub bagian dengan para staff' disamping itu ada beberapa meja kerja staff yang berdekatan dengan dapur dan tata ruangan yang dinilai kurang rapi, prabot yang tersusun kurang rapi kurang menggambarkan kenyamanan, sehingga situasinya menjadi kurang nyaman.

Pada masalah diatas maka tidak akan baik bila dibiarkan begitu saja. Lingkungan kerja tidak dapat dilakukan secara langsung dalam prosesnya di perusahaan atau instansi, namun lingkungan kerja berstatus langsung dengan perusahaan yang mengeluarkan perusahaan. Lingkungan kerja yang baik dapat meningkatkan semangat dan semangat kerja para karyawan dan lingkungan kerja yang baik juga baik untuk kenyamanan pribadi maupun dalam hal mengerjakan tugas-tugas, lingkungan buruk yang tidak memadai dan kurang nyaman dapat menurunkan semangat dan motivasi kerja pada akhirnya. menjadi menurun.

Menurut (Rivai \& Mulyadi, 2012) bahwa Disiplin kerja merupakan alat yang dipergunakan para manajer untuk berkomunikasi dengan karyawan untuk mereka. Untuk meningkatkan kesadaran dan kesedian dalam segala bentuk peraturan perusahaan.

Selain itu berbagai aturan / norma yang ditetapkan oleh lembaga-lembaga memiliki peran yang sangat penting dalam menciptakan kedisiplinan agar para pegawai / pasien dapatmelakukan dan melaksanakan peraturan tersebut. Aturan / norma itu biasanya diikuti. Sanksi tersebut dapat berupa teguran baik lisan, skorsing, penurunan bahkan hingga pemecatan kerja tergantung dari besarnya gangguan yang dilakukan oleh pegawai / karyawan. Hal itu dimaksudkan agar para pegawai bekerja dengan disiplin dan memperbaiki atas pekerjaannya.

Berlandaskan informasi dari wawancara terbuka yang dilakukan oleh beberapa karyawan Samsat Painan pada bulan Juni 2017, ternyata masih ada gangguan yang kurang sesuai dengan idealisme, yaitu masih ada beberapa kelemahan yang ditunjukkan oleh karyawan, mereka kurang termotivasi dalam pekerjaannya. Informasi yang diberikan kepada orang-orang lain yang masih memiliki waktu untuk masuk, masih membutuhkan yang tertunda, dan sebagian besar yang masih bisa menggunakan sarana kantor dengan baik.

Penelitian Dian Mardiono (2014) penelitiannya berjudul Pengaruh Motivasi Dan Disiplin Kerja Terhadap Kepuasan Kerja Karyawan. Penelitiannya menghasilkan secara simultan diperoleh nilai uji f 52.516 dengan sig sebesar 0,000 dengan simpulan motivasi, dan disiplin kerja secara simultan berpengaruh signifikan terhadap kepuasan kerja karyawan. Berdasarkan perhitungan secara parsial nilai sig motivasi sebesar 0,000 , dan nilai sig kepuasan kerja sebesar 0,000 $<(\alpha) 0,05$, sehingga motivasi, dan disiplin kerja berpengaruh signifikan terhadap kepuasan kerja karyawan.

Penelitian yang dilakukan oleh Quinerita dan Mahendra (2015) yang meneliti tentang Pengaruh Lingkungan Kerja Terhadap Kepuasan Kerja Karyawan Lapangan Departemen Grasberg Power Distribution PT. Freeport Indonesia. Hasil penelitian ini menunjukkan bahwa secara parsial faktor lingkungan kerja fisik dan lingkungan kerja non fisik memiliki pengaruh yang 
positif dan signifikan terhadap kepuasan kerja karyawan. Secara simultan faktor lingkungan kerja fisik dan lingkungan kerja non fisik signifikan mempengaruhi kepuasan kerja karyawan di departemen grasberg power distribtuion PT. Freeport Indonesia.

Penelitian yang dilakukan oleh Made Nensy Dwijayanti dan A.A Sagung Kartika Dewi (2015) yang meneliti Pengaruh Kompensasi Dan Lingkungan Kerja Terhadap Kepuasan Kerja Karyawan Pada Perusahaan Daerah Air Minum Tirta Mangutama Badung. Hasil penelitian ini menunjukkan bahwa berdasarkan hasil pembahasan yang telah diuraikan, maka simpulan yang diperoleh adalah sebagai berikut: (1) kompensasi secara serempak dan parsial berpengaruh signifikan terhadap kepuasan kerja karyawan pada pdam.tirta mangutama basung; (2) lingkungan kerja secara parsial berpengaruh signifikan terhadap kepuasan kerja karyawan pada pdam. Tirta mangutama badung; dan (3) variabel lingkungan kerja merupakan variabel yang berpengaruh lebih kuat daripada kompensasi terhadap kepuasan kerja karyawan pada pdam. Tirta mangutama badung.

Berdasarkan perumusan masalah, landasan teori dan tinjauan penelitian terdahulu yang telah dikemukakan, maka berikut ini dapat dikembangkan hipotesis dalam penelitian ini sebagai berikut:

Hipotesis 1 Diduga lingkungan kerja berpengaruh positif dan signifikan terhadap kepuasan kerja karyawan pada kantor Samsat Painan.

Hipotesis 2 Diduga disiplin kerja berpengaruh poisitif dan signifikan terhadap kepuasan kerja karyawan pada kantor Samsat Painan.

Hipotesis 3 Diduga lingkungan kerja dan disiplin kerja berpengaruh positif dan signifikan terhadap kepuasan kerja karyawan pada kantor Samsat Painan.

\section{METODE PENELITIAN}

Penelitian ini menggunakan metode penelitian kuantitatif. Penelitian kuantitatif menurut Sugiyono (2009:8) dalam (Erlina et al., 2015) adalah metode penelitian yang berlandaskan pada filsafat positivme, digunakan untuk meneliti pada populasi atau sampel tertentu, pengumpulan data menggunakan instrumen penelitian, serta analisis data bersifat kuantitatif statistik dengan tujuan untuk menguji hipotesis yang telah ditetapkan diteliti untuk melihat bagaimana lingkungan kerja dan bagaimana kerja karyawan pada kantor Samsat Painan. Menurut (Sugiyono, 2013), kata kunci kausal komparatif adalah tipe penelitian dengan bentuk hubungan sebab akibat antara dua variabel atau lebih.

Dilihat dari segi cara memperolehnya, maka penelitian ini menggunakan sumber data, yaitu: Data Primer, yakni data yang belum tersedia sehingga untuk menjawab masalah penelitian, data harus diperoleh dari sumber aslinya. Data primer dalam penelitian ini diperoleh dengan menyebar kuesioner secara langsung pada responden yaitu kepada karyawan karyawan kantor Samsat Painan.

Dalam penelitian ini, metode pengumpulan data yang digunakan adalah:

1. Kuesioner atau Angket

Yaitu metode yang digunakan untuk mendapatkan data primer, dengan cara membuat suatu daftar pertanyaan yang secara sistematis dengan tujuan mendapatkan data yang diinginkan dan diedarkan kepada responden untuk dijawab. 
2. Studi Kepustakaan/Dokumentasi

Yaitu mempelajari maupun data praktis dari kepustakaan sehubungan dengan judul atau pokok bahasan yang akan diteliti. Dalam melakukan dokumentasi penulis mengunakan sarana kepustakaan seperti; buku teks, jurnal ilmiah, dan majalah untuk mendapatkan data atau informasi yang dibutuhkan.

Analisis data yang digunakan dalam penelitian ini yaitu :

\section{Uji Instrumen}

\section{Uji Validitas}

Uji validitas dalam penelitian ini digunakan untuk menguji kevalidan kuisioner. Validitas menunjukan sejauh mana ketepatan dan kecermatan suatu alat ukur dalam melakukan fungsi ukurnya ( Azwar. 2003 ). Perhitungan ini akan dilakukan dengan bantuan komputer program SPSS ( Statistical Package For Social Science ). Untuk menentukan nomor nomor item yang valid dan yang gugur, perlu dikonsultasikan pada tabel $r$ product moment. Kriteria penilaian uji validitas adalah:

a. Apabila $r$ hitung $>r$ tabel (pada taraf signifikansi 5\%), maka dapat dikatakan item kuisioner tersebut valid.

b. Apabila $r$ hitung $<\mathrm{r}$ tabel ( pada taraf signifikan 5\%). Maka dapat dikatakan item kuisioner tersebut tidak valid.

Menutur santoso ( 2000), ada dua sarat penting yang berlaku pada sebuah angket yaitu keharusan sebuah angket untuk valid dan reliabel. Suatu angket dikatakan valid jika pertanyaan pada suatu angket mampu mengungkapkan sesuatu yang diukur oleh angket tersebut. Sedangkan suatu angket dikatakan reliabel jika jawaban seseorang terhadap pertanyaan konsisten dari waktu kewaktu. Dimana validitas data diukur dengan membandingkan $r$ hasil dengan $r$ tabel ( $r$ Product moment ), jika :

a. $\mathrm{r}$ hasil $>\mathrm{r}$ tabel, data valid

b. $\quad r$ hasil $<\mathrm{r}$ tabel, data tidak valid

\section{Uji Reliabilitas}

Realiabilitas adalah suatu indeks yang menunjukan pengukuran mengasilkan hasil yang dapat di percaya. Menurut (Azwar, 2003) rumus koefisien cronbach Alpha digunakan unuk menguji kosioner realiabel atau tidak.

Nilai Cronbach Alpha pada penelitian ini digunakan nilai 0.6 dengan asumsi bahwa daftar pertanyaan yang diuji akan dikatakan reliabel bila nilai Cronbach Alpha = 0.6 (Nunally, 1996). Kehandalan suatu alat ukur jika menunjukkan semakin tinggi jika koefisien reliabilitas mendekati angka satu.

\section{Analisis Deskriptif}

Analisis deskriptif dapat digunakan untuk memberikan gambaran mengenai faktor-faktor yang mempengaruhi variabel. Analisis ini dapat menghubungkan satu variabel dengan variabel lainnya. Untuk mendapatkan skor masing masing indikator dan pertanyaan pertanyaan kuesioner, secara umum analisis deskriptif yang dilakukan peneliti ini dikemukakan oleh Arikunto (2006) bahwasanya untuk mendapatkan rata rata skor masing-masing indikator dan pertanyaan-pertanyaan yang di dapatkan dalam kuesioner dapat di pakai rumus sebagai berikut : 
Keterangan :

$$
\text { rata }- \text { rata skor }=\frac{F 1 \times b s}{n}
$$

$F 1=$ Jumlah total skor respon jawaban responden

bs $\quad=$ Skala likert $1-5$

$n \quad=$ Jumlah Responden

Sedangkan mencari tingkat pencapaian jawaban responden digunakan rumus sebagai berikut (Arikunto,2006).

\section{Uji Asumsi Klasik}

$$
\mathrm{TCR}=\frac{\text { Rata-rata }}{\text { skala teringgi }} \times 100 \%
$$

\section{a. Uji Normalitas}

Uji normalitas bertujuan menguji apakah dalam model regresi, variabel pengganggu atau residual memiliki distribusi normal. Menurut Umar, (2013:181) untuk mendeteksi uji normalitas dapat dikakukan dengan menggunkan melalui analisa grafik. Analisa grafik ini dapat digunakan untuk menentukan normalitas dengan melihat grafik PP-Plot. Apabila titik-titik terdistribusi mengikuti garis diagonal, maka model regresi dapat dinyatakan berdistribusi normal (Umar, (2013:181).

\section{b. Uji Heteroskedastisitas}

Uji heteroskedastisitas menguji apakah dalam model regresi terjadi ketidaksamaan variance dari residual data yang ada (Umar, 2013:179). Model regresi yang baik adalah tidak mengalami gejala heteroskedastisitas. Untuk melihat atau mendeteksi ada atau tidaknya heteroskedastisitas dapat dilakukan dengan melihat Grafik Plott (Scatter plot). Jika ada pola tertentu, serta titik-titik yang ada membentuk pola tertentu yang teratur (bergelombang, melebar, kemudian menyempit), maka mengindikasikan telah terjadi heteroskedastisitas. Dan jika tidak ada pola yang jelas, serta titik-titik menyebar datas dan dibawah angka 0 pada sumbu Y, maka tidak terjadi heteroskedastisitas.

\section{c. Uji Multikolinieritas}

Pengujian ini dilakukan agar dapat melihat apakah pada model regresi ditemukan adanya korelasi antar variabel independen. Jika terjadi korelasi yang kuat, maka dapat dikatakan telah terjadi masalah multikolinearitas dalam model regresi. (Umar, 2013:177) menyatakan pedoman suatu model regresi yang bebas multikolinearitas adalah:

1) Mempunyai nilai VIF (Variance Influence Faktor) lebih kecil dari 10 .

2) Mempunyai angka Tolerance lebih besar dari 0,10.

\section{Analisis Regresi Linier Berganda}

Data yang diperoleh dalam penelitian ini akan dianalisis dengan memakai metode statistik untuk menguji hipotesis dan variabel yang di gunakan. Data tersebut dianalisis dengan menggunakan SPSS (Statistical Program for Science). Uji regresi linear berganda merupakan teknik statistik yang digunakan untuk menguji pengaruh beberapa variabel bebas terhadap variabel terikat (Sekaran, 2006:299). Persamaan regresi linier penelitian ini yakni sebagai berikut: 


$$
\begin{aligned}
& \mathrm{Y}=\alpha+\beta 1 \mathrm{X} 1+\beta 2 \mathrm{X} 2 \\
& \text { Di mana: } \\
& \mathrm{Y} \quad=\text { Kepuasan Kerja } \\
& \alpha \quad=\text { Konstanta } \\
& \beta 1 \quad=\text { Koefisien Regresi Lingkungan Kerja } \\
& \beta 2 \quad=\text { Koefisien Regresi Disiplin Kerja } \\
& \mathrm{X} 1 \quad=\text { Lingkungan Kerja } \\
& \mathrm{X} 2 \quad=\text { Disiplin Kerja } \\
& \text { Pengujian Hipotesis }
\end{aligned}
$$

\section{Pengujian Hipotesis}

Uji statistik diperlukan dalam proses analisis data penelitian untuk menginterprestasikan data dan menarik kesimpulan yang logis berdasarkan data tersebut.

\section{Uji F Statistik}

Uji simultan dengan F-test bertujuan untukmengetahui pengaruh bersama-sama variabel independen terhadap variabel dependen (Nugroho, 2005). Hasil F-test ini pada output SPSS dapat dilihat pada tabel ANOVA. Hasil F-test menunjukkan variabelindependen secara bersama-sama berpengaruh terhadap variabeldependen jika p-value (pada kolom Sig.) lebih kecil dari level of significant yang ditentukan atau $\mathrm{F}$ hitung (pada kolom F) lebih besar dari $\mathrm{F}$ tabel. $\mathrm{F}$ tabel dihitung dengan cara df $1=\mathrm{k}-1$, dan df $2=\mathrm{n}-\mathrm{k}, \mathrm{k}$ adalah jumlah variabel dependen dan independen dengan pengujian hipotesis sebagai berikut :

Kriteria Pengujian:

a. Jika nilai signifikansi > 0,05, maka H0 diterima dan Ha ditolak. Artinya variabel independen secara simultan tidak berpengaruh signifikan terhadap variabel dependen.

b. Jika nilai signifikansi $<0,05$, maka H0 ditolak dan Ha diterima. Artinya variabel independen secara simultan berpengaruh signifikan terhadap variabel dependen.

\section{Uji t Statistik}

Uji t bertujuan untuk mengetahui besarnya pengaruh masingmasing variabel independen secara individual (parsial) terhadap variabel dependen (Nugroho, 2005). Hasil uji ini pada output SPSS dapat dilihat pada tabel Coefficients ${ }^{a}$. Nilai dari uji t dapat dilihat dari p-value (pada kolom $\mathrm{Sig}$ ) dengan pengujian hipotesis sebagai berikut :

a. Jika nilai t-hitung $>\mathrm{t}$-tabel, maka variabel indenpenden secara persial (sendiri-sendiri) berpengaruh terhadap dependen.

b. Jika nilai t-hitung < $\mathrm{t}$-tabel, maka variabel indenpenden secara persial (sendiri-sendiri) tidak berpengaruh terhadap dependen.

\section{Uji Koefisien Determinasi (R2)}

Ghozali (2009), koefisien determinasi pada intinya mengukur seberapa jauh kemampuan sebuah model dalam menerangkan variasi variabel dependen. Uji iniertujuan untuk menetukan proporsi atau presentase total variasi dalam variabel terikat yang diterangkan oleh variabel bebas. Apabila analisi yang digunakan adalah regresi sederhana, maka yang digunakan adalah nilai $R$ square, namun apabila analisis yang digunakan adalah regresi berganda maka yang digunakan adalah Adjusted $R$ Square. 
Hasil perhitungan Adjusted $R^{2}$ dapat dilihat pada output Model Summary. Pada kolom Adjusted $R^{2}$ dapat diketahui berapa persentase yang dapat dijelaskan oleh variabel variabel bebas terhadap variabel terikat, sedangkan sisanya dipengaruhi atau dijelaskan oleh variabel variabel lain yang tidak dimasukan dalam model penelitian.

\section{HASIL ANALISA DAN PEMBAHASAN}

Uji Instrumen

\section{Uji Validitas}

a. Uji Validitas Kualitas Produk

Berdasarkan hasil pengujian validitas yang telah dilakukan diperoleh ringkasan terlihat pada tabel 1 di bawah ini :

Tabel 1

Lingkungan Kerja (X1)

\begin{tabular}{ccccc}
\hline \multirow{2}{*}{ Variabel } & $\begin{array}{c}\text { Item } \\
\text { pertanyaan }\end{array}$ & $\begin{array}{c}\text { Batasan Nilai } \\
\text { Valid }\end{array}$ & $\begin{array}{c}\text { corrected item } \\
\text { total } \\
\text { correlation }\end{array}$ & Ket \\
\hline \multirow{5}{*}{$\begin{array}{c}\text { Lertanyaan 1 } \\
\text { Kerja }\end{array}$} & 0.300 & 0.681 & Valid \\
\cline { 2 - 5 } & Pertanyaan 2 & 0.300 & 0.452 & Valid \\
\cline { 2 - 5 } & Pertanyaan 3 & 0.300 & 0.844 & Valid \\
\cline { 2 - 5 } & Pertanyaan 4 & 0.300 & 0.608 & Valid \\
\cline { 2 - 5 } & Pertanyaan 5 & 0.300 & 0.848 & Valid \\
\cline { 2 - 5 } & Pertanyaan 6 & 0.300 & 0.633 & Valid \\
\cline { 2 - 5 } & Pertanyaan 7 & 0.300 & 0.856 & Valid \\
\cline { 2 - 5 } & Pertanyaan 8 & 0.300 & 0.838 & Valid \\
\cline { 2 - 5 } & Pertanyaan 9 & 0.300 & 0.596 & Valid \\
\hline
\end{tabular}

Sumber: Data primer diolahdengan SPSS 16.0(2018)

Berdasarkan data Tabel 1.hasil pengujian validitas lingkungan kerja yang dirancang dengan 10 item pertanyaan. Secara keseluruhan semua item pertanyaan sudah bernilai valid hal ini ditunjukan oleh nilai corrected item total correlation> 0.3. Yang memiliki nilai corrected item total correlation ( $\mathrm{r}$ ) diatas 0.3 . dianggap sebagai item pertanyaan yang dapat mewakili variable lingkungan kerja pada pengujian lebih lanjut dalam menjelaskan variable lingkungan kerja pada pengujian hipotesis item pertanyaan tersebut.

b. Uji Validitas Disiplin Kerja

Berdasarkan hasil pengujian validitas yang telah dilakukan diperoleh ringkasan terlihat pada tabel 2 di bawah ini : 
Tabel 2

Disiplin Kerja (X2)

\begin{tabular}{ccccc}
\hline \multirow{2}{*}{ Variabel } & $\begin{array}{c}\text { Item } \\
\text { pertanyaan }\end{array}$ & $\begin{array}{c}\text { Batasan Nilai } \\
\text { Valid }\end{array}$ & $\begin{array}{c}\text { Corrected } \\
\text { Item-Total } \\
\text { Correlation }\end{array}$ & Ket \\
\hline \multirow{5}{*}{$\begin{array}{c}\text { Pertanyaan 1 } \\
\text { Disiplin }\end{array}$} & 0.300 & 0.789 & Valid \\
\cline { 2 - 5 } & Pertanyaan 2 & 0.300 & 0.656 & Valid \\
\cline { 2 - 5 } & Pertanyaan 3 & 0.300 & 0.589 & Valid \\
\cline { 2 - 5 } & Pertanyaan 4 & 0.300 & 0.732 & Valid \\
\cline { 2 - 5 } & Pertanyaan 5 & 0.300 & 0.519 & Valid \\
\cline { 2 - 5 } & Pertanyaan 6 & 0.300 & 0.623 & Valid \\
\cline { 2 - 5 } & Pertanyaan 7 & 0.300 & 0.792 & Valid \\
\cline { 2 - 5 } & Pertanyaan 8 & 0.300 & 0.774 & Valid \\
\cline { 2 - 5 } & Pertanyaan 9 & 0.300 & 0.741 & Valid \\
\cline { 2 - 5 } & Pertanyaan 10 & 0.300 & 0.545 & Valid \\
\hline
\end{tabular}

Sumber: Data primer diolahdengan SPSS 16.0(2018)

Berdasarkan data Tabel 2.hasil pengujian validitas disiplin kerja yang dirancang dengan 10 item pertanyaan. Secara keseluruhan semua item pertanyaan sudah bernilai valid hal ini ditunjukan oleh nilai corrected item total correlation $>0.3$. Yang memiliki nilai corrected item total correlation ( $\mathrm{r}$ ) diatas 0.3. dianggap sebagai item pertanyaan yang dapat mewakili variable disiplin kerjapada pengujian lebih lanjut dalam menjelaskan variable disiplin kerjapada pengujian hipotesis item pertanyaan tersebut.

c. Uji Validitas Kepuasan Kerja

Berdasarkan hasil pengujian validitas yang telah dilakukan diperoleh ringkasan terlihat pada tabel 3 di bawah ini :

Tabel 3

Disiplin Kerja (Y)

\begin{tabular}{ccccc}
\hline \multirow{2}{*}{ Variabel } & $\begin{array}{c}\text { Item } \\
\text { pertanyaan }\end{array}$ & $\begin{array}{c}\text { Batasan Nilai } \\
\text { Valid }\end{array}$ & $\begin{array}{c}\text { Corrected } \\
\text { Item-Total } \\
\text { Correlation }\end{array}$ & Ket \\
\hline \multirow{5}{*}{$\begin{array}{c}\text { Pertanyaan 1 } \\
\text { Kepuasan } \\
\text { Kerja }\end{array}$} & Pertanyaan 2 & 0.300 & 0.655 & Valid \\
\cline { 2 - 5 } & Pertanyaan 3 & 0.300 & 0.871 & Valid \\
\cline { 2 - 5 } & Pertanyaan 4 & 0.300 & 0.655 & Valid \\
\cline { 2 - 5 } & Pertanyaan 5 & 0.300 & 0.518 & Valid \\
\cline { 2 - 5 } & Pertanyaan 6 & 0.300 & 0.359 & Valid \\
\cline { 2 - 5 } & Pertanyaan 7 & 0.300 & 0.765 & Valid \\
\cline { 2 - 5 } & Pertanyaan 8 & 0.300 & 0.384 & Valid \\
\cline { 2 - 5 } & Pertanyaan 9 & 0.300 & 0.461 & Valid \\
\hline
\end{tabular}

Sumber: Data primer diolahdengan SPSS 16.0(2018)

Berdasarkan data Tabel 3 hasil pengujian validitas kepuasan kerja yang dirancang dengan 10 item pertanyaan. Secara keseluruhan semua item pertanyaan sudah bernilai valid hal ini ditunjukan oleh nilai corrected item total correlation> 0.3 . Yang memiliki nilai 
corrected item total correlation ( $\mathrm{r}$ ) diatas 0.3. dianggap sebagai item pertanyaan yang dapat mewakili variable kepuasan kerja pada pengujian lebih lanjut dalam menjelaskan variable kepuasan kerja pada pengujian hipotesis item pertanyaan tersebut.

\section{Uji Reliabilitas}

Uji reabilitas bertujuan untuk menilai sejauh mana jawaban dari konsumen dapat memberikan hasil yang relative tidak berbeda (konsisten) bila dilakukan pengukuran ulang terhadap subjek yang sama. Pengujian reabilitas dilakukan dengan menggunakan pendekatan Cronbach's Alpha. Instrument yang handal (reliable) apabila memiliki Cronbach's Alpha lebih dari 0.60 (Nugroho,2005). berikut hasil pengujian pada Tabel 4.

\section{Tabel 4}

\section{Hasil Uji Reabilitas}

\begin{tabular}{llll}
\hline \multicolumn{1}{c}{ Variabel } & Batas Nilai & Cronbach's Alpha & Keterangan \\
\hline Lingkungan kerja & 0.600 & 0.923 & Reliable/handal \\
\hline Disiplin kerja & 0.600 & 0.912 & Reliable/handal \\
\hline Kepuasna kerja & 0.600 & 0.875 & Reliable/handal \\
\hline
\end{tabular}

Sumber: Data primer diolah dengan SPSS 16.0(2018)

Berdasarkan sajian Tabel 4 hasil pengujian menemukan nilai koefisien Cronbach's Alpha . yang secara keseluruhan sudah reliable atau handal. dengan nilai koefisien Cronbach's Alpha besar dari 0.6. Oleh karena itu kesemua variabel diatas telah dapat digunakan pada pengujian lebih lanjut.

\section{Uji Asumsi Klasik}

\section{Uji Normalitas}

Berdasarkan output dari analisis dapat dilakukan pendeteksian sifat normalitas dari suatu model persamaan regresi yaitu dengan melihat grafik p-p plot. Adapun hasilnya adalah sebagai berikut ini :

\section{Gambar 1}

\section{Hasil Uji Normalitas}

\section{Normal P-P Plot of Regression Standardized Residual}

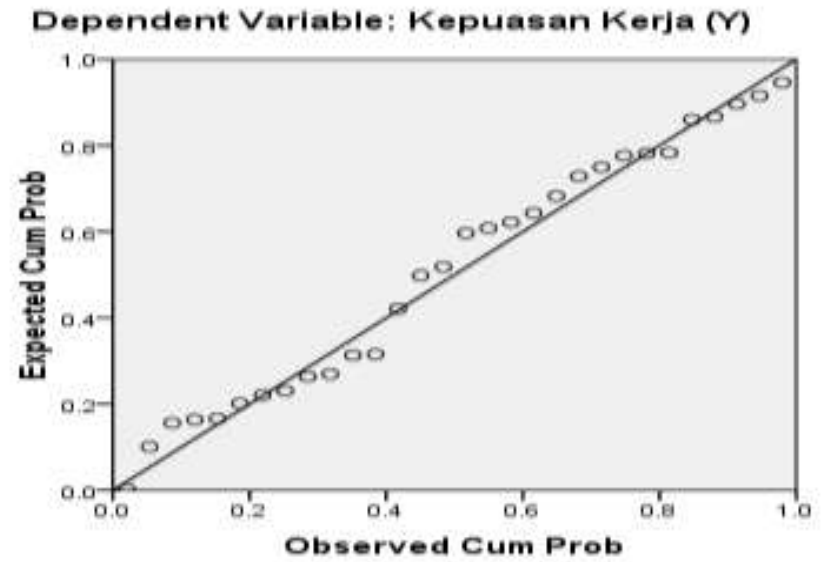

Sumber: Data primer diolah dengan SPSS 16.0(2018) 
Berdasarkan grafik diatas dapat dilihat bahwa titik titik hanya menyebar di sekitar garis lurus. Artinya penyebaran data terbukti normal.

\section{Uji Heteroskedaktisitas}

Pengujian ini dilakukan untuk memprediksi regresi yang digunakan cocok atau tidak. Dalam SPSS metode yang sering digunakan untuk mendeteksi adanya heteroskedastisitas yaitu dengan melihat ada tidaknya pola tertentu pada scatterplot yang menunjukkan hubungan antara Regression Studentised Residual dengan Regression Standardized Predicted Value. Dasar pengambilan keputusan berkaitan dengan gambar tersebut adalah:

a. Jika terdapat pola tertentu, yaitu jika titik-titiknya membentuk pola tertentu dan teratur (bergelombang, melebar kemudian menyempit), maka diindikasikan terdapat masalah heteroskedastisitas.

b. Jika tidak terdapat pola yang jelas, yaitu jika titik-titknya menyebar, maka diindikasikan tidak terdapat masalah heteroskedastisitas.

Dari hasil uji hetersokedastisitas yang dilakukan terhadap penelitian ini diperoleh sebagai berikut :

\section{Gambar 2}

\section{Hasil Uji Heteroskedastisitas}

Scatterplot

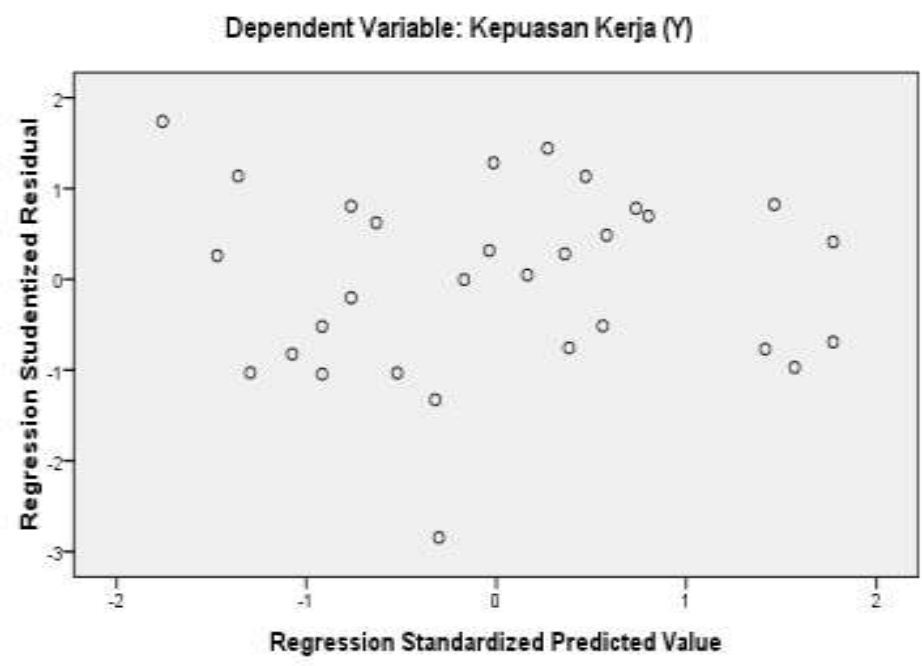

Sumber: Data primer diolah dengan SPSS 16.0(2018)

Dari gambar diatas, terlihat bahwa tidak terdapat pola yang jelas, yaitu titik-titiknya menyebar, maka diindikasikan tidak terdapat masalah heteroskedastisitas. Jadi dapat disimpulkan model regresi tidak mengandung adanya heteroskedastisitas.

\section{Uji Multikolinearitas}

Uji multikolinearitas yakni guna untuk menguji apakah pada model regresi ditemukan adanya korelasi antar variabel independen. Jika terjadi korelasi, maka dinamakan terdapat problem Multikolinearitas. Model regresi yang baik seharusnya tidak terjadi korelasi di antara variabel independen. 
Deteksi tidak adanya Multikolinearitas yakni dengan melihat besaran VIF (Variance Inflation Factor) dan Tolerance (Ghozali, 2006):

a. Mempunyai nilai VIF $<10$

b. Mempunyai angka TOLERANCE $>10 \%$

Mengacu pada kedua pendapat di atas maka berdasarkan hasil penelitian yang telah dilakukan dapat diperoleh nilai :

Tabel 5

Hasil Uji Multikolinearitas

\begin{tabular}{lccc}
\hline \multicolumn{1}{c}{ Variabel } & Tol & VIF & Keterangan \\
\hline Lingkungan Kerja (X1) & .829 & 1.206 & Tidak Terjadi Multikolinearitas \\
\hline Disiplin Kerja (X2) & .829 & 1.206 & \\
\hline
\end{tabular}

Sumber: Data primer diolah dengan SPSS 16.0(2018)

Dari hasil analisis, didapat dua variabel bebas (independent) dalam penelitian ini nilai VIF-nya di bawah 10 dan tolerance nya 1 . Ini berarti bahwa tidak terjadi multikolinearitas antara variabel bebas tersebut. Dengan demikian, dapat disimpulkan bahwa variabel bebas (independent) memenuhi persyaratan asumsi klasik tentang multikolinieritas.

\section{Analisis Regresi Linear Berganda}

Regresi bertujuan untuk menguji hubungan pengaruh antara satu variabel terhadap variabel lain. Variabel yang dipengaruhi disebut variabel tergantung atau dependen, sedangkan variabel yang mempengaruhi disebut variabel bebas atau variabel independen (Nugroho, 2005):

\section{Tabel 6}

Hasil Analisa Regresi Linear Berganda

\begin{tabular}{lc}
\hline \multicolumn{1}{c}{ Variabel } & KoefisienRegresi \\
\hline Konstanta & 13.856 \\
\hline Lingkungan kerja (X1) & 0.297 \\
\hline Disiplin kerja (X2) & 0.358 \\
\hline
\end{tabular}

Sumber: Data primer diolahdengan SPSS 16.0(2018)

Dari data diatas dapat dibuat persamaan regresi berganda sebagai berikut :

$\mathrm{Y}=13.856+0.297 \mathrm{X} 1+0.358 \mathrm{X} 2$

Dari persamaan tersebut dapat diambil kesimpulan bahwa :

a. Dari model persamaan regresi linear bergnada di atas dapat diketahui bahwa nilai konstanta sebesar 13.856, yang berarti bahwa tanpa adanya pengaruh dari variable lingkungan kerja dan isiplin kerja, kepuasan kerja karyawan telah mencapai 13.856 .

b. Koefisien regresi variabel lingkungan kerja (X1) sebesar 0.297. Hal ini berarti apabila nilai lingkungan kerja meningkat sebesar satu satuan maka kepuasan kerja akan meningkat sebesar 0.297 dalam setiap satuannya. Dengan asumsi variabel lain tidak mengalami perubahan atau konstan.

c. Koefisien regresi variabel disiplin kerja (X2) sebesar 0.358 . Hal ini berarti apabila nilai disiplin kerja meningkat sebesar satu satuan maka kepuasan kerja akan meningkat sebesar 0.358 dalam setiap satuannya. Dengan asumsi variabel lain tidak mengalami perubahan atau konstan. 


\section{Pengujian Hipotesis}

\section{Uji Stimultan Dengan Uji F}

Uji statistik $\mathrm{F}$ pada dasarnya digunakan untuk melihat pengaruh variabel independen terhadap variabel dependen secara bersama-sama. Dimana pada penelitian ini untuk melihat pengaruh lingkungan kerja dan disiplin kerja terhadap kepuasan kerja.

Tabel 7

Hasil Uji F

\begin{tabular}{lccc}
\hline Variabel Bebas & Signifikan & Batas Sigifikan & Keterangan \\
\hline $\begin{array}{l}\text { Lingkungan kerja } \\
\text { dan disiplin kerja }\end{array}$ & 0.000 & 0.05 & Signifikan \\
\hline Surber: Dataprimer &
\end{tabular}

Sumber: Data primer diolahdengan SPSS 16.0(2018)

Berdasarkan tabel diatas diperoleh nilai signifikansi kerja lebih kecil dari alpha yaitu $0,002<0,05$. Berdasarkan analisis di atas disimpulkan bahwa Ha diterima artinya secara bersama-sama lingkungan kerja dan disiplin kerja berpengaruh positif signifikan terhadap kepuasan kerja pada karyawan di Kantor Samsat Painan.

\section{Uji Parsial Dengan T}

Uji statistik $\mathrm{T}$ pada dasarnya digunakan untuk melihat pengaruh variabel independen terhadap variabel dependen secara parsial.Dimana pada penelitian ini untuk melihat pengaruh lingkungan kerja dan disiplin kerja terhadap kepuasan kerja.

Tabel 8

Hasil Uji T

\begin{tabular}{lrcc}
\hline Variabel Bebas & Signifikan & Batas Sigifikan & Keterangan \\
\hline Lingkungan kerja & 0.002 & 0.05 & Signifikan \\
\hline Disiplin kerja & 0.000 & 0.05 & Signifikan \\
\hline
\end{tabular}

Sumber: Data primer diolahdengan SPSS 16.0(2018)

Hipotesis pertama diperoleh nilai signifikansi pada variabel lingkungan kerja lebih kecil dari alpha yaitu 0,002 <0,05. Berdasarkan analisis di atas disimpulkan bahwa Ha diterima artinya lingkungan kerja berpengaruh positif signifikan terhadap kepuasan kerja pada karyawan di Kantor Samsat Painan.

Hipotesis kedua diperoleh nilai signifikansi pada variabel disiplin kerja lebih kecil dari alpha yaitu sebesar 0,000 $<0,05$. Berdasarkan hasil di atas disimpulkan bahwa Ha diterima artinya disiplin kerja berpengaruh positif signifikan terhadap kepuasan kerja pada karyawan di Kantor Samsat Painan.

\section{Uji Koefisien Determinasi $\left(\mathbf{R}^{2}\right)$}

Koefisien Determinasi digunakan untuk melihat berapa besar pengaruh proporsi variasi perubahan variabel independen (variabel bebas) secara keseluruhan terhadap variabel dependen (variabel terikat) pada tabel sebagai berikut : 
Sumber: Data primer diolahdengan SPSS 16.0(2017)

Pada tabel diatas didapatkan nilai Rsquare 0.653 artinya sebanyak 65,3\% variabel lingkungan kerja dan disiplin kerja mempengaruhi kepuasan kerja karyawan dan sisanya 34,7\% dipengaruhi oleh variabel lain diluar variabel penelitian.

\section{PEMBAHASAN}

\section{Pengaruh Lingkungan Kerja Terhadap Kepuasna Kerja Karyawan Pada Kantor Samsat Painan}

Berdasarkan penelitian diperoleh hasil nilai signifikansi pada variabel lingkungan kerja lebih kecil dari alpha yaitu $0,002<0,05$. Berdasarkan analisis di atas disimpulkan bahwa Ha diterima artinya lingkungan kerja berpengaruh positif signifikan terhadap kepuasan kerja pada karyawan di Kantor Samsat Painan.

Sejalan dengan penelitian terdahulu yang dilakukan oleh Wibowo, (2014) tentang pengaruh lingkungan kerja terhadap kepuasan kerja karyawan (studi pada karyawan PT. Telekomunikasi Indoensia Tbk. Kandatel Malang) diperoleh hasil terdapat pengaruh lingkungan kerja terhadap kepuasna kerja karyawan dengan $\mathrm{p}=0,000$ dan penelitian Nugraha, (2016) tentang pengaruh lingkungan kerja, budaya organisasi dan disiplin kerja terhadap kepuasan kerja guru diperoleh hasil terdapat hubungan lingkungan kerja terhadap kepuasna kerja guru dengan nila $\mathrm{p}=$ 0,003 .

Sedarmayanti (2001) menyatakan "Kondisi lingkungan kerja dikatakan baik apabila manusia dapat melaksanakan kegiatan secara sehat, aman dan nyaman" karena biasanya orang akan bersemangat untuk bekerja apabila lingkungan kerjanya baik secara fisik maupun secara non fisik (hubungan) dan sesuai dengan yang mereka harapkan, lingkungan kerja dapat menciptakan gairah kerja sehingga produktifitas dan prestasi kerja meningkat dan akan mencapai hasil yang memuaskan begitupun sebaliknya jika lingkungan kerja yang tidak baik akan menurunkan semangat kerja karyawan sehingga berdampak terhadap kinerja karyawan.

Berdasarkan temuan di atas, menunjukkan bahwa lingkungan kerja mempunyai pengaruh signifikan terhadap kepuasan kerja. Tingkat signifikansi memiliki makna bahwa lingkungan kerja fisik memiliki peranan yang penting utnuk meningkatkan kepuasan kerja. Hal ini terjadi karena lingkungan kerja fiisk dan non fisik seperti struktur tugas, desain pekerjaan, pola kepemimpinan, pola kerja sama dan budaya organisasi semakin baik, maka kepuasan kerja karyawan pun juga semakin membaik.

\section{Pengaruh Disiplin Kerja Terhadap Kepuasna Kerja Karyawan Pada Kantor Samsat Painan}

Berdasarkan penelitian diperoleh hasil nilai signifikansi pada variabel disiplin kerja lebih kecil dari alpha yaitu $0,000<0,05$. Berdasarkan analisis di atas disimpulkan bahwa Ha diterima artinya disiplin kerja berpengaruh positif signifikan terhadap kepuasan kerja pada karyawan di Kantor Samsat Painan. 
Sejalan dengan penelitian sebelumnya yang dilakukan oleh Mardiono, (2014) tentang pengaruh motivasi dan disiplin kerja terhadap kepuasan kerja karyawan diperoleh hasil terdapat pengaruh disiplin kerja terhadap kepuasan kerja karyawan dan juga penelitian yang dilakukan oleh Riyanto, (2016) tentang pengaruh motivasi kerja dan disiplin kerja terhadap kepuasan kerja karyawan Bank Tabungan Negara Yogyakarta diperoleh hasil terdapat pengaruh disiplin kerja terhadpa kepuasan kerja karyawan.

Disiplin dalam bekerja yakni faktor yang harus ada pada pegawai yang menginginkan tercapainya kepuasan dalam pekerjaannya. Disiplin kerja bisa berupa ketepatan waktu dalam kerja, ketaatan terhadap tugas-tugas yang diberikan kepadanya, serta pemanfaatan sarana secara baik. Dengan adanya disiplin kerja akan meningkatkan semangat dan kegairahan kerja karyawan yang tinggi ini akan mendorong karyawan untuk bekerja secara lebih produktif sehingga pada gilirannya akan dapat meningkatkan produktivitas kerja karyawan. Paradigma lembaga-lembaga saat ini yang akan berkembang dan maju sangat membutuhkan pegawai yang berdisiplin tinggi dalam pekerjaannya. Mereka yang mempunyai semangat tinggi, patuh terhadap aturan yang ditetapkan lembaga, kreatif dan dapat memanfaatkan sarana dengan baik akan mampu untuk bersaing dalam kondisi saat ini yang semakin kompetitif (Hasibuan, 2006).

Perusahaan berperan dalam mengelola karyawan agar mematuhi segala peraturan, norma yang telah di tetapkan oleh perusahaan sehingga para karyawan bekerja dengan disiplin dan efektif. Kedisiplinan adalah kesadaran dan kesediaan seseorang dalam menaati semua peraturan organisasi dan norma sosial yang berlaku (Hasibuan, 2001: 193). Berbagai aturan/norma yang ditetapkan oleh suatu perusahaan memiliki peran yang sangat penting dalam menciptakan kedisiplinan agar para karyawan dapat mematuhi dan melaksanakan peraturan tersebut. Aturan/norma itu biasanya diikuti sanksi yang diberikan bila terjadi pelanggran. Sanksi tersebut bisa berupa teguran baik lisan/tulisan, skorsing penurunan posisi bahkan sampai pemecatan kerja tergantung dari besarnya pelanggran yang dilakukan oleh karyawan. Hal itu dimaksudkan agar para karyawan bekerja dengan displin dan bertanggung jawab atas pekerjaannya. Bila karyawan memiliki disiplin kerja yang tinggi, diharapkan akan mampu menyelesaikan tugas dengan cepat dan tepat sehingga timbul kepuasan kerja.

\section{Pengaruh Lingkungan Kerja dan Disiplin Kerja Terhadap Kepuasan Kerja Karyawan Pada Kantor Samsat Painan}

Berdasarkan penelitian diperoleh hasil nilai signifikansi kerja lebih kecil dari alpha yaitu 0,002 <0,05. Berdasarkan analisis di atas disimpulkan bahwa $\mathrm{Ha}$ diterima artinya secara bersama-sama lingkungan kerja dan disiplin kerja berpengaruh positif signifikan terhadap kepuasan kerja pada karyawan di Kantor Samsat Painan denga nilai Rsquare 0.653 artinya sebanyak 65,3\% variabel lingkungan kerja dan disiplin kerja mempengaruhi kepuasan kerja karyawan dan sisanya $34,7 \%$ dipengaruhi oleh variabel lain diluar variabel penelitian.

Kantor Samsat Painan selalu memfasilitasi untuk meningkatkan kedisiplinan karyawan dan juga menicptakan lingkungan kerja yang nyaman, dilupakan dalam tindakan, bertanggung jawab pada pekerjaannya masing-masing, bekerja sesuai dengan waktu yang ditentukan oleh perusahaan, hadir tepat waktu, sesuaikan cara kerja dan mampu menggunakan perlengkapan kerja dengan tepat. 
Jika karyawan bekerja sesuai dengan peraturan yang berlaku, maka akan terjadi positif terhadap kinerja karyawan.

Alasan ini diperkuat oleh teori Hasibuan (2004) yang menjelaskan bahwa kedisiplinan yakni kesadaran dan kesediaan seseorang mentaati semua peraturan perusahaan dan norma-norma social yang berlaku. Maka disiplin kerja yang tinggi merupakan salah satu hal yang dapat meningkatkan kepuasan karyawan yaitu dengan usaha agar karyawan tetap sadar dan bersedia untuk patuh dan taat terhadap aturan yang ada di perusahaan sehingga dengan adanya kerelaan dari karyawan untuk disiplin terhadap aturan perusahaan hal tersebut dapat meningkatkan kepuasan karyawan.

\section{SIMPULAN}

Berdasarkan hasil penelitian tentang Pengaruh Lingkungan Kerja dan Disiplin Kerja Terhadap Kepada Kantor Samsat Painan maka dapat disimpulkan dengan uraian sebagai berikut:

1. Lingkungan kerja berpengaruh positif signifikan terhadap kepuasan kerja pada karyawan di Kantor Samsat Painan.

2. Disiplin kerja berpengaruh positif signifikan terhadap kepuasan kerja pada karyawan di Kantor Samsat Painan.

3. Lingkungan kerja dan disiplin kerja berpengaruh positif signifikan terhadap kepuasan kerja pada karyawan di Kantor Samsat Painan.

\section{UCAPAN TERIMAKASIH}

Terima kasih peneliti sampaikan kepada Bapak Febryandhie Ananda, SE, M.Si selaku ketua STIE "KBP" Padang yang telah memberikan fasilitas dan kemudahan kepada penulis sehingga studinya dapat berjalan dengan lancar. Ibu Lidhya Martha, SE, MM selaku wakil ketua STIE "KBP" Padang. Ibu Febsri susanti S.E.I, MM selaku Ketua Program Studi manajemen Sekolah Tinggi Ilmu Ekonomi "Keuangan, Perbankan dan Pembangunan" Padang, sekaligus pembimbing skripsi yang telah membimbing penulis dari awal skripsi sampai saat sekarang ini, membimbing penulis dengan penuh kesabaran, terimakasih atas degala kesempatan yang ibu berikan semoga nasehat-nasehat yang ibu berikan memberikan manfaat bagi saya.

\section{DAFTAR PUSTAKA}

Aziz, N. (2019). Pengaruh Lingkungan Kerja Terhadap Kinerja Yang Dimediasi Oleh Motivasi Kerja Karyawan Rocky Plaza Hotel Padang. https://doi.org/10.17605/OSF.IO/E4C59

Dessler. (2011). Manajemen sdm. Manajemen sdm.

Erlina, r., gaya, p., berbelanja, h., terhadap, f., erlina, r., yulisetiarini, d., ... unej, u. J. (2015). Pengaruh gaya hidup berbelanja dan keterlibatan fashion terhadap perilaku pembelian impulsif mahasiswa strata 1 manajemen fakultas ekonomi universitas jember.

Hariani, w., isyandi, b., \& machasin. (2015). Pengaruh kompetensi, pelatihan dan 
motivasi terhadap kinerja karyawan pt. Pertamina (persero) refinery unit ii dumai. Jurnal economica, i(1), 115-124.

Hasibua, \& n, m. S. P. (2011). Manajemen sumber daya manusia. Edisi revisi jakarta: bumi aksara. Https://doi.org/10.1017/cbo9781107415324.004

Irvianti, s. L. S. D. (2014). Analisis pengaruh stres kerja dan organizational citizenship behavior terhadap kepuasan kerja dan dampaknya terhadap retensi karyawan di ford jakarta pusat. Msdm, vol. 5 no., 39-48.

Ismail, a., john, c., boerhannoeddin, a., md rasip, o., wan ismail, w. K., azman, i., ... ismail, w. K. W. (2011). Kepuasan kerja adalah peramal kepada keinginan berhenti kerja secara sukarela: satu kajian di sebuah penguasa tempatan. Jurnal kemanusiaan, 19(issn:1675-1930), 11-26.

Kreitner, r., \& kinicki, a. (2014). Perilaku organisasi organizational behavior. In 1 (pp. 1-272).

Marihot tua efendi hariandja. (2002). Manajemen sumber daya manusia. Pengadaan, pengembangan, pengkompensasian, dan peningkatan produktiivitas pegawai.

Mayliza, R. (2019). Pengaruh Kompensasi Finansial, Lingkungan Kerja Dan Motivasi Kerja Terhadap Kinerja Pegawai Pada Kantor PDAM Kota Payakumbuh. https://doi.org/10.17605/OSF.IO/DZXAF

Rivai, v., \& mulyadi, d. (2012). Kepemimpinan dan perilaku organisasi. In kepemimpinan dan perilaku organisasi (pp. 34-35).

Scott, c., myers, k. K., glaser, b. G., holton, j., prevention, c. For d. C. And, connell, k. M., ... shepard, j. M. (2013). Coping resources inventory for stress. Burns, 33(1), 1. Https://doi.org/http://dx.doi.org.proxyremote.galib.uga.edu/10.1016/j.addbeh.2014.12.005

Sedarmayanti. (2009). Pengaruh lingkungan kerja terhadap kinerja karyawan (studi pada karyawan kantor pelayanan pajak pratama malang utara). Jurnal administrasi bisnis, 8(22).

Siswanto. (2010). Manajemen sumber daya manusia (mdsm), pendekatan normatif versus kontekstual. Buletin penelitian sistem kesehatan, 13(1), 32-41.

Sugiyono. (2013). Metode penelitian. Alfabetha, bandung (vol. Xx). Https://doi.org/10.1007/s13398-014-0173-7.2

Sutrisno. (2013). Kajian pengaruh struktur organisasi , komitmen karyawan, dan pemahaman tujuan operasi terhadap penerapan total production maintanance ( tpm ) serta implikasinya pada kinerja karyawan. Kontigensi, 1(1), 57-67. 
Swandhita, g. B. A., kebayantini, n. L. N., \& kamajaya, g. (2016). Peran desa adat kuta dalam peningkatan kualitas sumber daya manusia (studi tentang eksistensi desa adat pada masyarakat perkotaan). Jurnal ilmiah sosiologi (sorot), 1(1).

Vera, o. :, simbolon, h., seno andri, h., \& si, m. (2016). Pengaruh pemberian motivasi dan disiplin kerja terhadap kinerja karyawan pada pt. Posindo (persero) kantor cabang pekanbaru. Jom fisip, 3(2). 